\title{
Street Tree Inventory and Tree Risk Assessment of Selected Major Roads in Kuala Lumpur, Malaysia
}

\author{
M. Sreetheran, M. Adnan, and A.K. Khairil Azuar
}

Abstract. Tree planting programs in Malaysia have progressed as planned. However, the subsequent management of the street trees, particularly at Kuala Lumpur City Hall, is not well undertaken due to inadequate information for management and maintenance purposes. There has never been a systematic tree survey conducted to inventory street trees in Kuala Lumpur. With this, a survey was conducted to collect comprehensive information on tree structure, species composition, species diversity, and tree defects and disorders. A total 2,191 street trees were surveyed. Key Words. Hazard Tree Management; Species Diversity; Tropics; Urban Trees; Urban Forest Management.

Street trees have been an integral part of the urban landscape. It was the Italian Renaissance and French Baroque influence that introduced the concept of planting rows and avenues of trees (Chevallerie 1983). Avenue tree planting was then adopted in the style formal English gardens during the eighteenth century. Although urban roads form only a small fraction of habitat corridor that trees can grow, trees provide substantial benefits ranging from physiological and economic benefits to the ameliorating of urban climate and mitigation of air pollution. A number of studies have shown the potential of the urban forest in providing physical environment and biological benefits (Aylor 1972; Smith 1990; McPherson 1994; Nowak 1994; Heisler et al. 1995; VanDruff et al. 1995; Neville 1996; Nowak et al. 2002). Besides important environmental services such as air and water purification, wind and noise filtering or microclimate stabilization, natural areas provide social and psychological services, which are of crucial significance for the liveability of modern cities and the well being of urban residents (Chiesura 2004). This is true particularly in the Western world where the social and cultural values of greenspace or street trees are well documented (Ulrich 1984; Jim 1992; Kaplan 1993; Schroeder and Ruffolo 1996; Sullivan and Kuo 1996; Tyrväinen 2001; Gorman 2004; Wolf 2004; Flannigan 2005).

The greening of urban Malaysia has focused primarily on beautification and has mainly been the province of horticulturists, landscapers, nursery workers, town planners, and architects, with negligible input from foresters. Perhaps for that reason, the term "landscaping" has been used more widely than "urban forestry" by government and private institutions, politicians, stakeholders, academics, and the public. However, this does not mean that tree planting has not been given a priority in Malaysia's cities. The earliest urban tree planting in Malaysia was recorded more than a century ago. Angsana (Pterocarpus indicus) was reported to have been planted in 1778 in Malacca (Koening 1894) and in Penang in 1802 (Burkill 1966). Owing to the beauty of its spreading crown and ease of propagation, $P$. indicus fast became a popular tree for urban planting and remained so until the 1990s in Malaysia and Singapore (Sanderson et al. 1997; Philip 1999). However, in 1935 these trees were reported to be dying rapidly in Malacca, Penang, and Singapore because of an unknown disease (Furtado 1935). Infected trees were removed immediately in an attempt to contain the spread of the disease, and there were no further reports until the same symptoms were observed again in 1985 in Singapore and on the East Coast of Peninsula Malaysia in 1992 (Sanderson et al.1997; Philip 1999). This time the causal agent was determined to be Fusarium oxysporum. As a result of this disease, the popularity of $P$. indicus dropped. Many argued that the high population of the species contributed to the epidemic. Pterocarpus indicus is currently being replaced in urban plantings by many other indigenous or exotic species in Malaysia.

More urban tree planting activities were undertaken with the establishment of the Federated Malay States Forestry Department in 1901. Through collaboration with the Department of Agriculture and the Public Works Department on roadside tree planting programs, local tree species such as Syzygium grande (kelat jambu), Millettia atropurpurea (tulang daing), Peltophorum pterocarpum (yellow flame), Mesua ferrea (penaga lilin), and Lagerstroemia speciosa (bungor) were widely planted in urban areas in the 1920s and 1930s (Adnan and Abdul Latiff 1993). Other species that were introduced during these years included Arfeuillea arborescens (hop tree), Ceiba pentandra (kapok tree), Andira inermis (brown heart), Spathodea campanulata (African tulip), Jacaranda filicifolia (jacaranda), and Stereospermum fimbriatum (snake tree) (Wee and Corlett 1986).

The first well-planned greening program in Malaysia began in the Federal Territory of Kuala Lumpur in 1973 with the establishment of the Beautification Unit under the Beautification Programmes of Kuala Lumpur (Ayoub 1989). In 1979, the unit was upgraded into a department, and today it is known as the Landscape and Urban Cleansing Control Department. The initial program of "No Roads Without Trees" set into motion a highly 
successful and sustained effort to maintain the green environment of the city wherever possible, and to bring greenery into the concrete jungle via extensive tree planting and landscaping. Among the popular tree species used were $P$. indicus, $P$. pterocarpum, Samanea saman (rain tree); Cinnamomum iners (wild cinnamon, Indian cassia, kayu manis), L. speciosa, Ficus benjamina (ficus), Swietenia macrophylla (mahogany), Delonix regia (red flame), Mimusops elengi (bunga tanjung), and M. atropurpurea.

The Kuala Lumpur City Hall (DBKL) started a serious urban tree planting program in 1973 with its famous "instant tree planting" concept, where large stem cuttings were used for planting. Some species of the trees has the capacity to root from stem, which created a green city almost overnight (Ayoub 1989). The city greening program of Kuala Lumpur was properly instituted in the planning process when the 1973 Act 267 was revised in the Federal Territory (Planning) Act of 1982 (Act 267), which stipulated the rules and regulations for planting, cutting, and conservation of urban trees. Apart from the tree planting program, an emphasis on urban tree planting has also been stated in the Kuala Lumpur Structure Plan (Kuala Lumpur City Hall 1984). This includes planting of shade trees, establishment of theme gardens, beautification and ornamental plantings, slope planting, roadside planting and beautification, and ground cover. In 1995, the Landscaping the Nation program was initiated, paying particular attention to tree planting along roads and rivers, together with the establishment of nurseries by state and local governments to ensure ample plant supply.

In March 1997, the Prime Minister launched a nationwide tree planting campaign with the aim of making Malaysia a "Garden Nation" by 2005. With this campaign the City Hall of Kuala Lumpur was given a mandate to plant 220,000 trees by the year 2000 (Nordin 1997). To date, more than 400,000 trees and six million shrubs have been planted. In addition, the expansion of highways and city link roads in Malaysia also invite more roadside tree plantings. Trees are grown as screens, to provide motorists with pleasant scenery by selectively blocking off unsightly features. Conversely, the trees may be grown for the benefit of people living next to motorways to screen traffic dust and noise and to provide a view of trees rather than of traffic (Salleh et al. 1990). This program has been carried out with the support of the private sector, city dwellers, and other government agencies. However, achieving the quantitative target is only one aspect of the campaign. Trees planted should not be neglected or left unattended, but should be nurtured and maintained to reach maturity and to avoid potential hazards and nuisances such as obstructing motorist's vision and damaging public properties.

Generally, Kuala Lumpur has achieved its objective in greening and beautifying the city. However, if one closely examines the aspects of planting from the urban forestry or arboricultural point of view, an entire range of problems emerge. These problems lead to poor performance in newly established as well as matured and old trees. To facilitate effective tree maintenance and management, information about the urban forest structure of Kuala Lumpur is vital. Detailed survey of a representative sample of urban trees can provide information on tree management, particularly in finding cause to the chronic problems of poor performance and low survival rate (Sanders 1981; Gilbertson and Bradshaw 1985). After nearly four decades of growing trees in Kuala Lumpur, it is especially important and timely to examine the status and management aspects of the street trees.
Consequently, this study focuses on street trees along five major roads in Kuala Lumpur with the aim of establishing information about the composition of street trees in Kuala Lumpur, to determine the diversity index and to assess the hazard status of the street trees in Kuala Lumpur. These roads were considered busy and prominent by DBKL. Apart from that, it was a request from DBKL to establish information on the trees at these streets primarily before moving to other streets in future.

\section{MATERIALS AND METHODS}

\section{Description of the Study Site}

Kuala Lumpur is located about $3^{\circ} 08^{\prime} \mathrm{N}$ and $101^{\circ} 44^{\prime} \mathrm{E}$. The city of Kuala Lumpur, which is equal in size to the federal territory officially called Wilayah Persekutuan, covers an area of $243 \mathrm{~km}^{2}$. Based on sources from Department of Statistics and assumptions derived from the existing number of housing units in Kuala Lumpur, it is estimated that the population for Kuala Lumpur in 2000 was 1.42 million people. Basically, Kuala Lumpur and the merging Klang Valley conurbation are located in a bowl-like topography with an opening into the Straits of Melaka and to the south towards Seremban. The rest is surrounded by relatively hilly topography reaching the foothills of the Main Range to the east. Kuala Lumpur is warm all year with temperatures ranges from $21^{\circ} \mathrm{C}$ to $35^{\circ} \mathrm{C}$. It rains year-round, but it's heaviest and most frequent during the Northeast Monsoon, which runs November to February. The total annual rainfall is high, averaging $2,370 \mathrm{~mm}$. The region is well served by road networks whose efficiency is hampered only by traffic congestion.

\section{Street Tree Survey}

A 100\% tree survey was conducted from April to October 2007. This survey was conducted on five major roads in Kuala Lumpur; namely Jalan Ampang, Jalan Sultan Ismail, Jalan Cheras, Jalan Raja Laut, and Jalan Kuching. These roads were chosen based on the request from DBKL. For the purpose of the survey, street trees are described as trees situated on the pavement or road verges between the curbs and the property lines.

A comprehensive range of qualitative as well as quantitative information was collected in the field. A form was used to record data such as types of species, tree structure, tree health and hazard status. A record form (Appendix) was designed, pilot tested, and finalized. The inventory was carried out by the authors in an attempt to collect data on tree structure in terms of height, trunk diameter at breast height $(\mathrm{DBH})$, crown spread, and their association with species composition, hazard status, and tree health and vigor. For identification purposes, each of these trees was tagged according to their street. Tree species were identified at the site. Where species identification was uncertain, leaf samples were collected and then taken to Forest Research Institute Malaysia Herbarium for keying. Tree height was obtained by using Hypsometer, while DBH and crown diameter were measured using diameter tape. Diameter at breast height was measured $1.4 \mathrm{~m}$ above ground level.

Since there is no complete record giving planting dates, tree status was classified into newly planted if the tree was still present with stakes and ties attached. When the tree passed this newly planted phase and no longer needed support it was noted as young. Trees were noted mature if they had reached a 
size and form in bole and crown commonly associated with the mature form of the species. The status "removed" is noted for those trees which were removed due to tree structural defects, because they died, or for the purposes of land development.

Tree condition was derived from a general observation from ground level from several directions in order to categorize the street trees as Good or Poor. Good trees referred to trees that were healthy, with trunk, branches, and the entire crown not displaying any impaired form and typical of the species. Poor trees should show symptoms of crown ill-health, such as yellowing of leaves or crown dieback or mechanical injuries that had affected the tree stability and longevity. Other aspects of tree condition under consideration were foliage color and density.

Apart from tree dimensions, data on the hazard status of the street trees was also taken. A tree is considered hazardous if it possesses some type of structural defect associated with a target, such as buildings, vehicles, pavements, or picnic areas where people and property are present. These identified hazardous street trees would have their hazard status determined following the method developed by Matheny and Clark (1994) as follows:

$$
\begin{aligned}
& \text { Hazard Rating }=\text { Failure Potential }+ \text { Size of Part }+ \\
& \text { Target Rating }
\end{aligned}
$$

where Failure Potential $=$ the most likely failure that the structural defect(s) will result in failure within the inspection period (Scale: 1-5). Size of Part $=$ rating of the size of the part most likely to fail. The larger the part that fails, the greater the potential damage (Scale: $1-5$ ). Target Rating = rating of the use and occupancy of the area that would be struck by the defective parts (Scale: 1-4).

Hazard Rating will be assigned according to the total rating given, with 3 to 5 points as the minimum value and 12 to 14 points being the maximum (Table 1). This rating will indicate the level of hazard and the extent of potential danger of the tree to potential targets. Using this rating system, the following hazard status has been assigned. In addition, the location of each species was also recorded by using DGPS (Differential Global Positioning System). This data will be used to develop a tree inventory system for DBKL. However the system will be developed in the second phase of the study.

\section{Table 1. Hazard rating.}

\begin{tabular}{ll}
\hline Hazard Status & Hazard Rating \\
\hline $12-14$ & Very High \\
$9-11$ & High \\
$6-8$ & Moderate \\
$3-5$ & Low \\
\hline
\end{tabular}

\section{Species Diversity}

The biological and genetic diversity level is a major factor in determining the stability and catastrophic tolerance of the roadside tree population (Richards 1983; Sun 1992). Therefore, it is pertinent to examine the current diversity level of the street trees in Kuala Lumpur to develop effective planning and management strategies for the street tree planting program. Diversity index is defined as a measure of the number of species in a community and their relative abundances (Lincoln et al. 1982). For the purpose of quantifying the species diversity in Kuala Lumpur, a simple measure of the inverse of Simpson's Diversity Index (SDI) was employed as derived by Sun (1992):

$$
\begin{aligned}
& \text { SDI }=\text { Inverse of Simpson's Index }=\Sigma \mathrm{N}_{\mathrm{j}} *\left(\Sigma \mathrm{N}_{\mathrm{j}}-1\right) / \\
& \sum \mathrm{N}_{\mathrm{j}}\left(\mathrm{N}_{\mathrm{j}}-1\right)
\end{aligned}
$$

where $N_{j}=$ number of individuals in the $j^{\text {th }}(j=1,2,3 \ldots n)$ group (species or genus), and $\mathrm{n}=$ the total number of groups in a particular population.

The Inverse of Simpson's Index can be interpreted as the expected number of samples with two randomly selected trees, of which one sample could have two trees belonging to the same species. The greater the SDI, the higher the diversity level. This SDI can be considered as the adjusted number of species in a street population based on species composition. This is because SDI equals the number of species if all the species are evenly represented in a population. Any street population with a SDI + $\mathrm{X}$ is diverse as much as an evenly-distributed population with $\mathrm{X}$ species. The SDI permits linear comparisons of species diversity levels between any street tree populations (Sun 1992).

\section{Analysis}

The collected data were compiled and analyzed using SPSS statistical software. For this study, the data were analyzed using descriptive statistics, such as means and frequency tabulation.

\section{RESULTS AND DISCUSSION}

\section{Species Composition}

A total of 2,291 trees comprising 35 species from 16 families were enumerated from five major roads in Kuala Lumpur. The highest number of trees were recorded along Jalan Kuching (646 trees) and Jalan Cheras (613 trees) (Figure 1). However, the most diverse tree species composition was found along Jalan Ampang (24 species) (Figure 2). The survey shows that $68.6 \%$ of the species were indigenous and $31.4 \%$ were exotic species, reflecting the trend towards planting more indigenous tree species in street planting by DBKL. When compared to the list of plants proposed by Chee and Ridwan (1984), the tree species composition can be considered rich, but when compared to the proposed list by Tho et al. (1983) the species composition was considered to be very poor. Another street tree survey, conducted by Adnan (1995) on 11 streets in Kuala Lumpur, only identifies 29 species, where $51 \%$ were indigenous and $49 \%$ were exotic. This reflects the trend toward planting more indigenous tree species by DBKL. It is interesting to note that there are many more potentially suitable indigenous tree species that are underused for street tree planting. The frequencies of individual tree species (Table 2) showed an overwhelming dominance by three main species which make up $72 \%$ of the total tree population. The three species were $P$. indicus (34\%), P. pterocarpum (20\%), and S. saman (18\%). The findings were similar to the results of urban tree studies by Jim (1985), Kunick (1987), and Gilbertson (1987), which indicate only a few major and popular species dominated in urban areas. However, study by Siti Rubiah (2008) in Kuching, Sarawak, indicated species such as Michellia sp. and $C$. iners dominated the roads. 


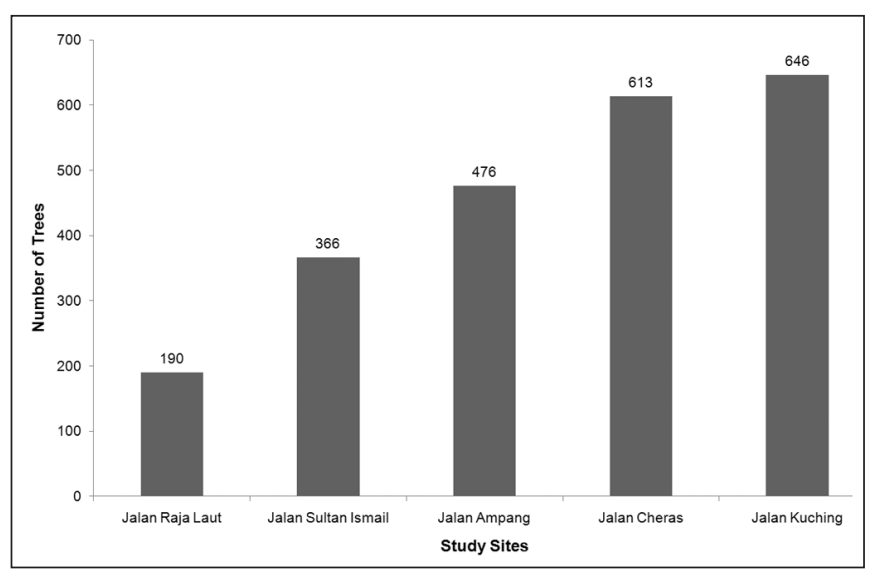

Figure 1. Frequency of trees graphed by road.

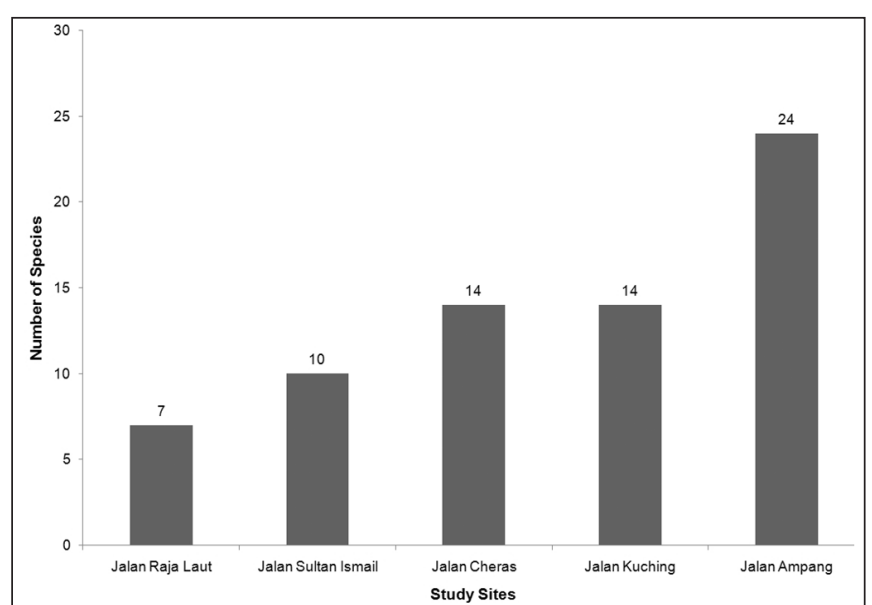

Figure 2. Species composition of street trees graphed by road.

Table 2. Species composition of the street trees surveyed.

\begin{tabular}{|c|c|c|c|c|}
\hline No. & Species & Frequency & Percent & Origin \\
\hline 1. & Mangifera caesia & 1 & 0.04 & indigenous \\
\hline 2. & Pithecellobium dulce & 1 & 0.04 & exotic \\
\hline 3. & Cratoxylum formosum & 1 & 0.04 & indigenous \\
\hline 4. & Artocarpus heterophyllus & 1 & 0.04 & indigenous \\
\hline 5. & Fagraea fragrans & 1 & 0.04 & indigenous \\
\hline 6. & Artocarpus altilis & 1 & 0.04 & indigenous \\
\hline 7. & Lepisanthes rubiginosa & 2 & 0.09 & indigenous \\
\hline 8. & Cinnamomum iners & 2 & 0.09 & indigenous \\
\hline 9. & Psidium guajava & 2 & 0.09 & indigenous \\
\hline 10. & Lagerstroemia speciosa & 2 & 0.09 & indigenous \\
\hline 11. & Mangifera indica & 3 & 0.13 & indigenous \\
\hline 12. & Plumeria spp. & 3 & 0.13 & exotic \\
\hline 13. & Garcinia atroviridis & 5 & 0.22 & indigenous \\
\hline 14. & Delonix regia & 5 & 0.22 & exotic \\
\hline 15. & Casuarina junghuhniana & 5 & 0.22 & exotic \\
\hline 16. & Gliricidia sepium & 6 & 0.26 & indigenous \\
\hline 17. & Roystonea regia & 6 & 0.26 & exotic \\
\hline 19. & Casuarina equisetifolia & 7 & 0.31 & indigenous \\
\hline 20. & Polyalthia longifolia var. pendula & 7 & 0.31 & exotic \\
\hline 21. & Terminalia catappa & 9 & 0.39 & indigenous \\
\hline 22. & Adenanthera pavonina & 9 & 0.39 & indigenous \\
\hline 23. & Syzygium campanulatum & 14 & 0.61 & indigenous \\
\hline 24. & Elaeis guineensis & 19 & 0.83 & indigenous \\
\hline 25. & Mimusops elengi & 26 & 1.13 & indigenous \\
\hline 26. & Ficus benjamina & 28 & 1.22 & indigenous \\
\hline 27. & Bauhinia blakeana & 28 & 1.22 & exotic \\
\hline 28. & Acacia holosericea & 46 & 2.01 & exotic \\
\hline 29. & Calophyllum inophyllum & 62 & 2.71 & indigenous \\
\hline 30. & Adonia merrillii & 88 & 3.84 & exotic \\
\hline 31. & Hopea odorata & 92 & 4.02 & indigenous \\
\hline 32. & Tabebuia pallida & 156 & 6.81 & exotic \\
\hline 33. & Samanea saman & 414 & 18.07 & exotic \\
\hline 34. & Pelthophorum pterocarpum & 452 & 19.73 & indigenous \\
\hline \multirow[t]{2}{*}{35.} & Pterocarpus indicus & 780 & 34.05 & indigenous \\
\hline & Total & 2,291 & 100.00 & \\
\hline
\end{tabular}

Pterocarpus indicus is fast growing, mostly evergreen but frequently deciduous. For decades, this species was a preferred choice of urban tree among the local town Councils in Malaysia from the British colonization period in the 17th century until the 1990s. A study conducted by Thaiutsa et al. (2008) also showed that $P$. indicus dominated the street trees of Bangkok, Thailand. However, $P$. indicus is no longer planted as a street tree because it is very susceptible to the wilt disease caused by $F$. oxysporum. Pterocarpus indicus is currently being replaced in urban plantings by many other indigenous or exotic species of Malaysia.

Pelthophorum pterocarpum and S. saman were the next most common species. Pelthophorum pterocarpum is an indigenous species and shed their leaves twice a year in Malaysia, remain bare for a week, and then develop new shoots (Wee 2003). 
This is an attractive ornamental tree when in bloom, with its crown covered with yellow flowers. Samanea saman is an exotic large deciduous tree with a wide-spreading crown growing to a height of $25 \mathrm{~m}$. These characteristics make this species an excellent shade tree. This species was brought to Singapore in 1876 from where it spread throughout Peninsular Malaysia.

The current study found that about $76.21 \%$ of the street trees belong to the Leguminoseae family (Figure 3). This indicates that trees from this family were more hardy and resilient to harsh roadside environment and may also be attributed to the ability of fixing nitrogen. This is followed by Bignoniaceae, which is solely contributed from the species Tabebuai pallida. This species has been planted widely in the city in because it is an attractive and fast growing tree with a spectacular display of flowers after a dry spell. The tree is suitable to provide shade and color along streets.

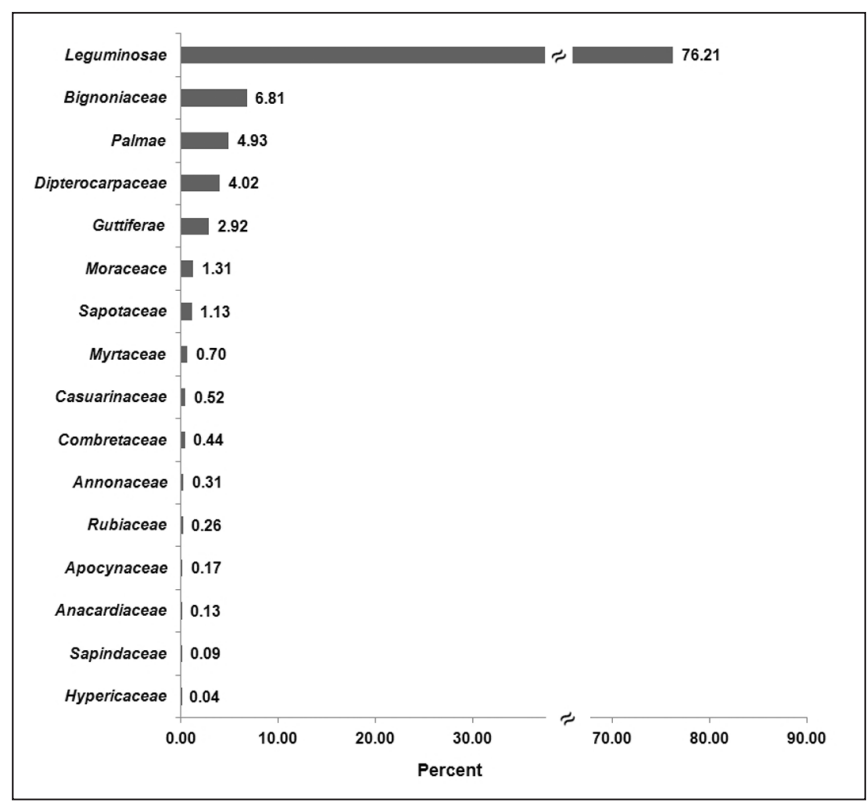

Figure 3. Species composition of street trees graphed by family.

\section{Species Diversity Index}

The analysis of the Species Diversity Index for the street trees in Kuala Lumpur has shown that the SDI was moderately low (SDI $=5.0$ ) when compared to the SDIs for other cities around the world calculated by Sun (1992). Since the SDI is a good indicator for diversity level In comparison with other tropical Asian cities, species diversity is poor. However, the frequencies of the occurrence of these species are shown in Table 3. Bassuk (1988) proposed a $5 \%$ criterion for urban street tree planting. She found that many underused tree species could adapt well to the urban environment and suggested that any species in a street tree population should not be more than $5 \%$. An equivalent SDI to this criterion is 20. To raise the SDI from the current level to 20, the diversity of many street tree populations must be more than doubled.

The dominance by few species is quite common in urban street tree population both in tropical and temperate cities (Valentine et al. 1978; Jim 1986; Jaenson et al. 1992; Chacalo et al. 1994; Adnan 1995). Miller (1988) and Jaenson et al. (1992) also found the overplanting or the exclusive planting of a single species (Trowbridge and Bassuk 2004). A classic example is from the epidemic of
Table 3. Tree species diversity at five major roads in Kuala Lumpur.

\begin{tabular}{|c|c|c|c|}
\hline Species & $(\mathrm{Nj})$ & $\mathrm{Nj}-1$ & $\mathrm{Nj}(\mathrm{Nj}-1)$ \\
\hline Mangifera caesia & 1 & 0 & 0 \\
\hline Pithecellobium dulce & 1 & 0 & 0 \\
\hline Cratoxylum formosum & 1 & 0 & 0 \\
\hline Artocarpus heterophyllus & 1 & 0 & 0 \\
\hline Fagraea fragrans & 1 & 0 & 0 \\
\hline Artocarpus altilis & 1 & 0 & 0 \\
\hline Lepisanthes rubiginosa & 2 & 1 & 2 \\
\hline Cinnamomum iners & 2 & 1 & 2 \\
\hline Psidium guajava & 2 & 1 & 2 \\
\hline Lagerstroemia speciosa & 2 & 1 & 2 \\
\hline Mangifera indica & 3 & 2 & 6 \\
\hline Plumeria spp. & 3 & 2 & 6 \\
\hline Garcinia atroviridis & 5 & 4 & 20 \\
\hline Delonix regia & 5 & 4 & 20 \\
\hline Casuarina junghuhniana & 5 & 4 & 20 \\
\hline Gliricidia sepium & 6 & 5 & 30 \\
\hline Roystonea regia & 6 & 5 & 30 \\
\hline Morinda citrifolia & 7 & 6 & 42 \\
\hline Casuarina equisetifolia & 7 & 6 & 42 \\
\hline Polyalthia longifolia var. pendula & 7 & 6 & 42 \\
\hline Terminalia catappa & 9 & 8 & 72 \\
\hline Adenanthera pavonina & 9 & 8 & 72 \\
\hline Syzygium campanulatum & 14 & 13 & 182 \\
\hline Elaeis guineensis & 19 & 18 & 342 \\
\hline Mimusops elengi & 26 & 25 & 650 \\
\hline Ficus benjamina & 28 & 27 & 756 \\
\hline Bauhinia spp. & 28 & 27 & 756 \\
\hline Acacia holosericea & 46 & 45 & 2,070 \\
\hline Calophyllum inophyllum & 62 & 61 & 3,782 \\
\hline Adonia merrillii & 88 & 87 & 7,656 \\
\hline Hopea odorata & 92 & 91 & 8,372 \\
\hline Tabebuia pallida & 156 & 155 & 24,180 \\
\hline Samanea saman & 414 & 413 & 170,982 \\
\hline Pelthophorum pterocarpum & 452 & 451 & 203,852 \\
\hline Pterocarpus indicus & 780 & 779 & 607,620 \\
\hline Total & $\begin{array}{c}2,291 \\
\text { SDI }=5.01\end{array}$ & 2,256 & $1,031,610$ \\
\hline
\end{tabular}

Dutch elm disease in cities of the United States (Grey and Deneke 1986; Philips 1993). Overplanting of a species could also lead to maintenance problems such as weak wood, the tendency to develop chlorosis, girdling roots, and messy fruits, but they are manageable only when planted in moderation (Trowbridge and Bassuk 2004). However, urban environments are particularly stressful and cause low diversity of street trees due to a low survival rate of newly planted trees and short life-span for many tree species (Sanders 1981; Richards 1983). Therefore, the SDI for Kuala Lumpur could be enhanced by selecting underused species as proposed by Tho et al. (1985) besides being based on both biological/genetic diversity and special characteristic of planting sites. In addition, species composition can also be influenced by encouraging the planting of certain species through campaigns organized by DBKL.

\section{Tree Structure}

Due to the absence of the information on age or planting date, the surveyed trees were categorized into four main groups, namely newly planted, young, mature, and removed. Figure 4 indicates that there were uneven distributions of the tree status on the five roads surveyed. Overall, mature trees $(96 \%)$ dominated the roadside. Most of these mature trees were $P$. indicus, S. saman, and P. pterocarpum. The distribution of trees by DBH classes (Figure 5) shows that majority of the trees are between the young 
$(42.7 \%)$ and medium $(43.9 \%)$ sized trees. Only about $6.7 \%$ of the trees surveyed were classified in the big sized group $(>70$ $\mathrm{cm})$. As was expected, the DBH values for $S$. saman were the highest in which majority of the trees were measured more than $70 \mathrm{~cm} \mathrm{DBH}$. In terms of tree height (Figure 6), the majority of trees were within 10 to $15 \mathrm{~m}$ height $(29.9 \%)$, while $27.6 \%$ were more than $20 \mathrm{~m}$ tall. Samanea saman and P. indicus were identified under the highest class $(>20 \mathrm{~m})$. The site constraints imposed by roadside planting limit crown development. Figure 7 shows the crown spread classes of the trees surveyed and it clearly indicated that the trees were restricted in their growth. Only $3.8 \%$ of the tree crown spreads were more than $20 \mathrm{~m}$. Crowns are also reduced by DBKL's pruning practices to maintain appropriate clearances to buildings and vehicles. However, a majority of the trees had a canopy spread between 5 to $10 \mathrm{~m}(33 \%)$ and 10 to $15 \mathrm{~m}(36 \%)$, which correlates with the majority of trees with height between 5 to $10 \mathrm{~m}$ and 10 to $15 \mathrm{~m}$.

The data gathered on tree health and vigor from the survey was based on visual assessment such as observing foliage colors, foliage density, and signs of diseases. Although no measurements, such as chlorophyll fluorescence, were measured using a Plant Efficient Analyzer, the visual assessment would at least provide a general overview of the health and vigor of the street trees in Kuala Lumpur. A total of $94.7 \%$ of the street trees were considered in good condition. This is a very high ratio despite the various biological and socio-physical environmental problems faced by street trees. Only $5.3 \%$ of the trees were considered to be in poor condition. Most of these trees were observed as dying trees and has disease (mostly wilting). A majority of the trees

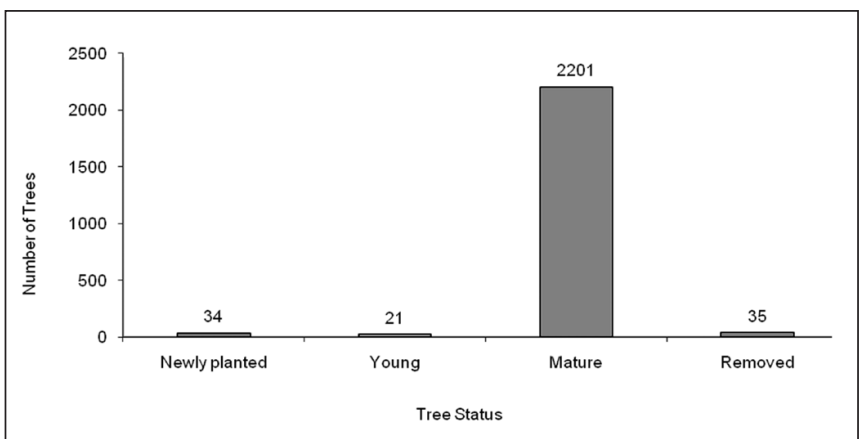

Figure 4. Status of street trees surveyed.

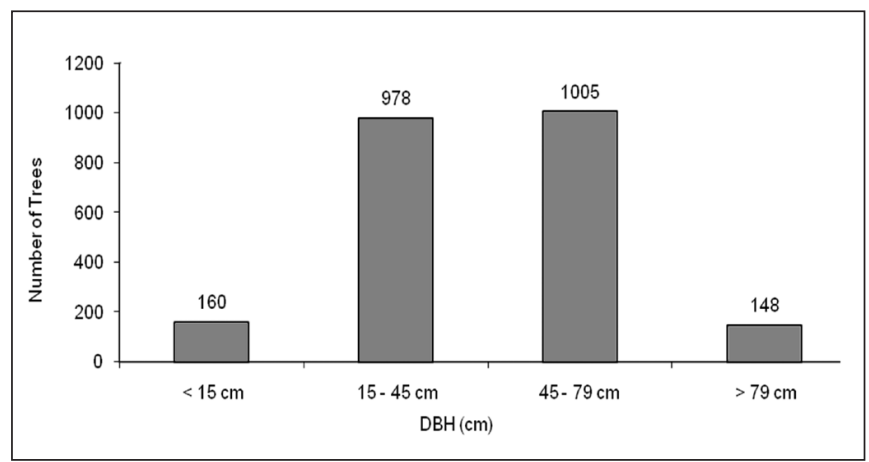

Figure 5. Distribution of DBH classes of trees surveyed.

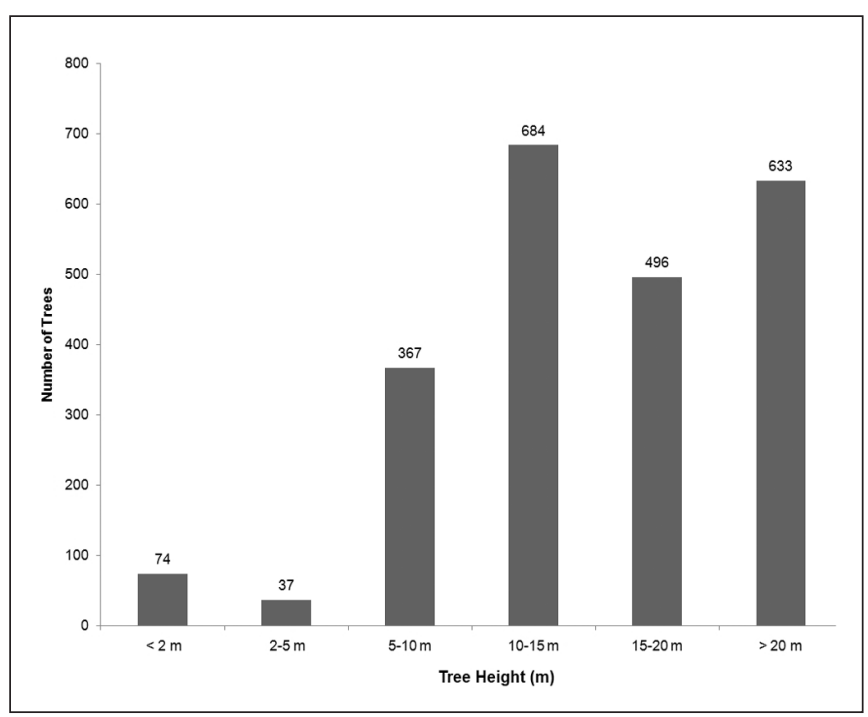

Figure 6. Distribution of tree height classes of street trees surveyed.

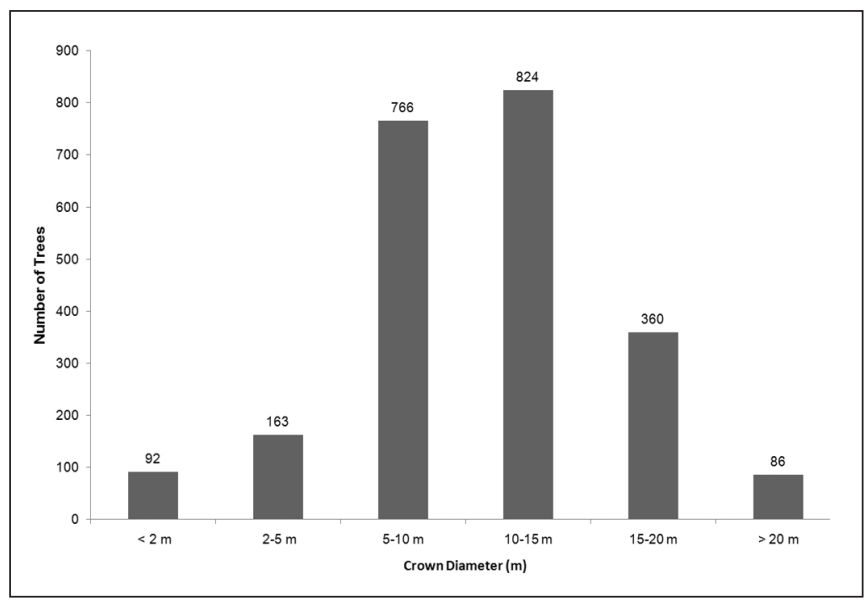

Figure 7. Distribution of crown spread classes of street trees surveyed.

were S. saman, $P$. indicus, and P. pterocarpum. This result was expected due the fact that these species were amongst the earliest planted as street trees in Malaysia. In addition, $P$. indicus are prone to the wilt disease caused by F. oxysporium (Philip 1999).

\section{Hazard Status}

The study authors found that $95.5 \%$ of the surveyed street trees in Kuala Lumpur were considered moderately hazard. Among the common structural defects found were dead branch/twigs. Although dead branch/twigs were not considered a serious threat, these trees are located adjacent to high target areas, such as along busy thoroughfares, and adjacent to buildings, which increases their risk rating. Apart from the target value, defect size is also taken into consideration during the hazard rating process. Forty trees $(1.8 \%)$ were considered highly hazard mainly because of the presence of decay, mostly in the branches and trunks. One $P$. indicus was rated highly hazardous due to extensive decay in the trunk and major branches as combined with the large size of parts 
and proximity to target. In addition, most of the trees, particularly $P$. indicus, were normally topped by DBKL. According to the International Society of Arboriculture, "topping" is the indiscriminate cutting back of tree branches to stubs or lateral branches that are not large enough to assume the terminal role. Topping is considered the best way to reduce the height of an overgrown tree in Malaysia. Trees that are topped normally produce vigorous water sprouts, which often grow back to its original height faster and even denser. However, these water sprouts form a weak attachment with the main trunk which makes the branches prone to failure. In addition, large branch stubs are normally left unclosed. This makes the stub vulnerable to fungal decay and insect invasion. Sometimes topped trees die because of the removal of substantial live crown, which functions to manufacture food for trees.

\section{CONCLUSION}

The findings from this study revealed that there are 2,191 trees comprising 35 species from 16 families, of which $68.6 \%$ of the species were indigenous species and $31.4 \%$ were exotic species. This figure reflects the trend toward planting more indigenous tree species in street planting by DBKL. The other important attribute of street trees was that despite the large number of species identified along the five major roads, domination by a small number of species was strongly evident, as with $P$. indicus, $P$. pterocarpum, and $S$. saman. These species were among the earliest street species planted by DBKL and this can be reflected through their sizes measured in terms of $\mathrm{DBH}$, height, and crown diameter. However, this result was also seems to be occurring in many other cities in the world.

The analysis of the inverse Simpson's Diversity Index for the street trees in Kuala Lumpur has shown that it was moderately low (SDI $=5$ ) when compared to the SDIs for other cities around the world, as calculated by Sun (1992). Since SDI is a good indicator for diversity level, which has implication on street tree management, efforts should be taken by City Hall to increase the species diversity to at least an index of 10 , which at this level the stability of street trees population could be maintained.

In terms of the hazard status of the street trees it seems that more than $95.5 \%$ of the street trees were moderately hazardous. However, this does not mean that these trees are vulnerable to citizens and buildings. The majority of the defects were only dead twigs/small branches. Special care needs to be taken because the streets are used constantly by the passerby in the city. City Hall needs to conduct a tree inventory and regular inspection in their area. With a tree inventory an arborist will learn a great deal about the defects in trees that have symptoms and signs of potential trouble and even the degree of risk. Through a systematic inspection, information of the potential tree hazards in a city can be revealed, leading to proactive management to reduce risk and enhance public safety (Anderson and Eaton 1986). In addition, documentation is the backbone of the inventory system (Wolowicz and Gera 2000). Records showing how and when trees were inspected and what action was taken can also be helpful evidence for the defendants in a trial. More significantly, records can help arborists plan inspection and maintenance work more efficiently, providing continuity through changes in program leadership and better justify requests for funding from the city (Anderson and Eaton 1986). A typical proactive maintenance schedule will involve a program dedicated to total Plant Health Care. The size and nature of the municipality will determine how to structure the Plant Health Care program (Consolloy 2000). Large cities will need to staff fulltime arborist and landscape crews to look after their larger investment of shade trees. Basically, well-maintained trees are safer, healthier with management costs being better budgeted.

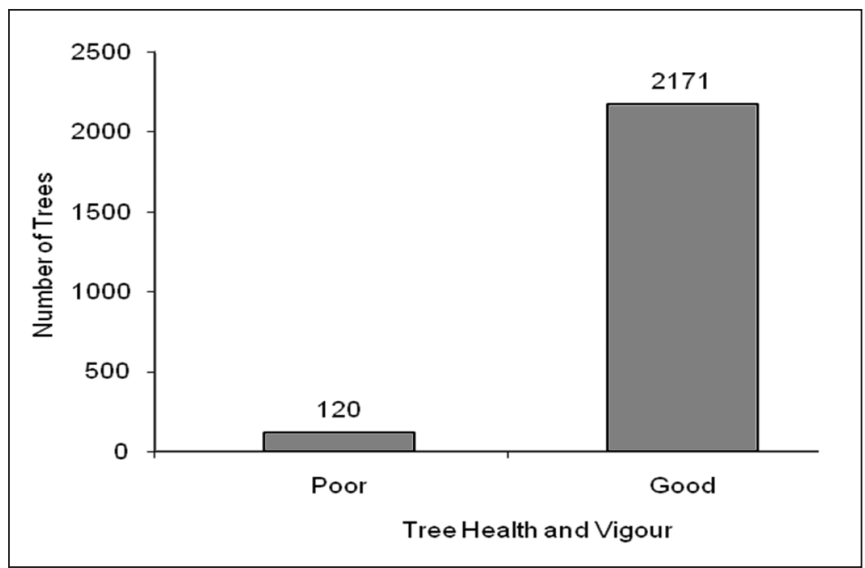

Figure 8. Tree Health and vigor.

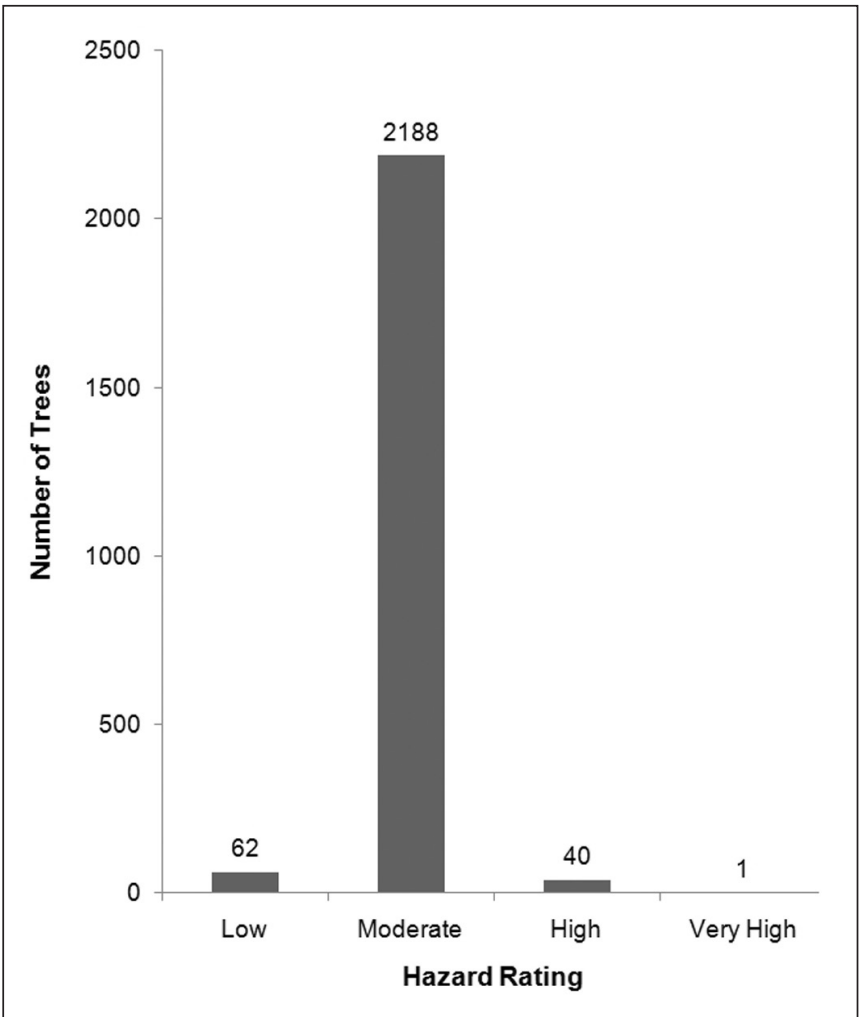

Figure 9. Hazard status of the street trees surveyed. 


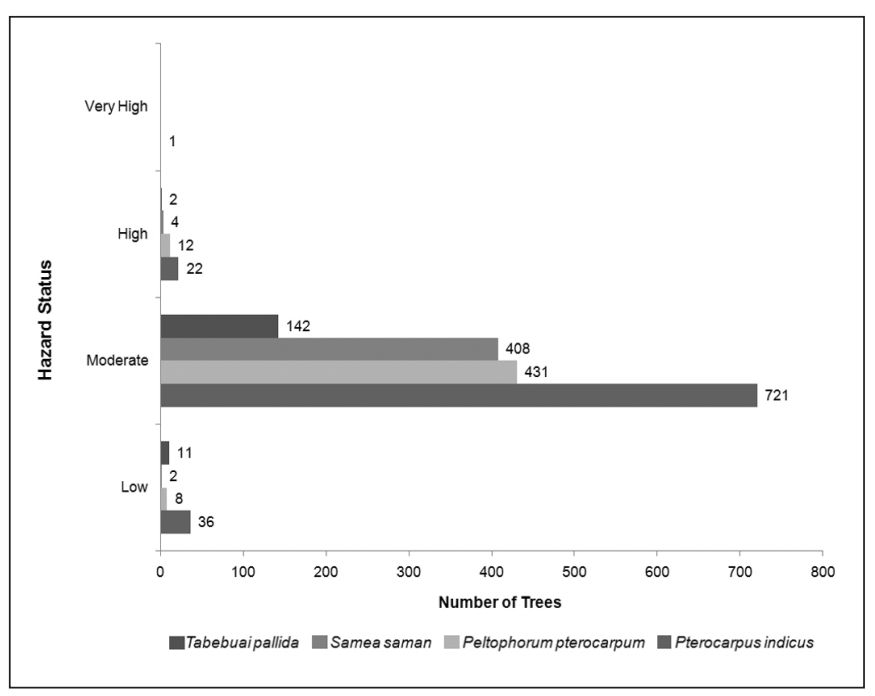

Figure 10. Hazard status of street trees surveyed graphed by dominant species.

There is still an urgent need to increase the number of professional landscape architects, arborist, landscape designers, and town planners. This will foster a greater appreciation of green elements and promote research, technology and the professional practice of tree planting and landscaping as a whole. Overall, there has been a positive move toward becoming a 'garden nation' from all parties, including the public, and Government and private agencies.

Acknowledgments. The authors wish to thank Kuala Lumpur City Hall (DBKL) for funding this project.

\section{LITERATURE CITED}

Adnan, M. 1995. Street Trees in Kuala Lumpur: Some Aspects of Structural and Arboriculture Management. MSc. thesis, Wye College, University of London. $50 \mathrm{pp}$.

Adnan, M., and M. Abdul Latiff. 1993. Perhutanan Bandar di Malaysia. pp. 265-283. In: S. Sham, H. Abdul Samad, and M.J. Jamaluddin (Eds.). Alam Sekitar dan Pengurusannya di Malaysia, Working Group on Urban Ecosystems, Malaysian National MAB Committee and Man and the Biosphere Programme, United Nations Educational, Scientific and Cultural Organization.

Anderson, L.M., and T.A. Eaton. 1986. Liability for damages caused by hazardous trees. Journal of Arboriculture 12:189-196.

Aylor, D.E. 1972. Noise reduction by vegetation and ground. Journal of Acoustical Society America 51(1):197-205

Ayoub, H. 1989. The role of city hall in improving the quality of urban green in Kuala Lumpur. Paper presented at the Seminar on Urban Green, Kuala Lumpur, Malaysia, August 7-9, 1989.

Bassuk, N.L.1988. Recommended urban trees. Urban Hort. Inst. Dept. of Floriculture and Ornamental Hort., Cornell University, Ithaca, NY.

Burkill, I.H. 1966. A dictionary of the economic products of the Malay Peninsula. 2 vols. Kuala Lumpur, Malaysia, Ministry of Agriculture and Cooperation.

Chacalo, A., A. Aldama, and J. Grabinsky. 1994. Street tree inventory in Mexico City. Journal of Arboriculture 17(7):173-183.

Chee, T.Y., and S. Ridwan. 1994. Fast growing species of trees suitable for urban roadsides and shade planting. Malaysian Forester 47(3):263-284.
Cheisura, A. 2004. The role of urban parks for the sustainable city. Landscape and Urban Planning 68:129-138.

Chevallerie, H.D.L. 1983. The ecology and preservation of street trees, pp. 345-355. In: A.D. Bradshaw, D.A. Goode, and E. Thorp (Eds.). Ecology and Design in Landscape, 24th Symposium of the British Ecological Society. Blackwell Scientific Publication, Oxford.

Consolloy, J.W. 2000. Planting and maintenance. pp. 189-203. In: J.E. Kuser (Ed.). Handbook of Urban and Community Forestry in the Northeast. Kluwer Academic/Plenum Publisher, New York.

Flanningan, J. 2005. An evaluation of residents' attitudes to street trees in southwest England. Arboricultural Journal 28:219-241.

Furtado, C.X. 1935. A disease of angsana tree. Journal of Malaysian Branch of the Royal Asiatic Society 13(2):163-192.

Gilbertson, P., and A.D. Bradshaw. 1985. Tree survival in cities. Arboricultural Journal 9:131-142.

Gorman, J. 2004. Residents' opinions on the value of street trees depending on tree allocation. Journal of Arboriculture 30(1):36-43.

Grey, G.W., and F.J. Deneke. 1995. Urban Forestry. John Wiley \& Sons Inc., NY. 277 pp.

Heisler, G.M., R.H. Grant, S. Grimmond, and C. Souch. 1995. Urban forests-cooling our communities? pp. 31-34. In: C. Kollin and M. Barratt (Eds.). Proc 7th National Urban Forest Conference. American Forests, Washington, D.C.

Jaenson, R., N. Bassuk, S. Schwager, and D. Headley. 1992. A statistical method for accurate and rapid sampling of urban street tree populations. Journal of Arboriculture 12(10):171-183

Jim, C.Y. 1985. Street trees in high density of Hong Kong. Journal of Arboriculture 12:257-263.

Jim, C.Y. 1986. Street Trees in High Density Urban Hong Kong. Journal of Arboriculture 12(10):257-263.

Jim, C.Y. 1992. Provenance of amenity-tree species in Hong Kong. Arboricultural Journal 16:11-23.

Kaplan, R. 1993. The role of nature in the context of the workplace. Landscape and Urban Planning 26(1-4):193-201.

Koening, J.G. 1894. Journal of a voyage from India to Siam and Malacca in 1779. Journal of the Straits Branch of the Royal Asiatic Society 26:58-201.

Kuala Lumpur Structure Plan. 1984. Dewan Bandaraya Kuala Lumpur (DBKL), Kuala Lumpur.

Kunick, W. 1987. Woody vegetation in settlements. Landscape Planning 14:56-78.

Lincoln, R.J., G.A. Boxshall, and P.A. Clark. 1982. A Dictionary of Ecology, Evolution and Systematics. Cambridge University Press, Cambridge, UK.

Matheny, N.P., and J.R. Clark. 1994. A Photographic Guide to the Evaluation of Hazard Trees in Urban Areas. International Society of Arboriculture, Champaign, IL.

McPherson, E.G. 1994. Cooling urban heat islands with sustainable landscapes. In: H.P. Rutherford, R.A. Rowntree, and P.C. Muick (Eds.).The Ecological City: Preserving and Restoring Urban Biodiversity, Amherst: University of Massachusetts Press.

Miller, R.W. 1988. Urban Forestry: Planning and Managing Urban Greenspaces. Prentice-Hall, Inc., Englewood Cliffs, New Jersey.

Neville, L.R. 1996. Urban Watershed Management: The Role of Vegetation. Ph.D. Dissertation, SUNY College of Environmental Science and Forestry, Syracuse, NY.

Nordin, A.R. 1997. Managing the garden city. pp. 73-84. In: M.T. Osman, M.S. Mustafa Kamal, M. Noorizan, A.R. Nordin, and O. Abdul Aziz (Eds.). Ke Arah Negara Taman: Wawasan dan Cabaran, Shah Alam, Malaysia, Institute of Landscape Architect Malaysia. 
Nowak, D.J. 1994. Air pollution removal by Chicago's urban forest. pp. 63-81. In: E.G. McPherson, D.J. Nowak, and R.A. Rowntree (Eds.). Chicago's Urban Forest Ecosystem: Results of the Chicago Urban Forest Climate Project. USD Forest Service General Technical Report NE-186. Radnor, PA.

Nowak, D.J. 2002. The effects of urban forests on the physical environment. pp. 22-42. In: T.B. Randrup, C.C. Konijendijk, T. Christophersen, and K. Nilsson (Eds.). Urban Forests and Trees. Springer, Amsterdam.

Philip, E. 1999. Wilt disease of angsana (Pterocarpus indicus) in Peninsular Malaysia and its possible control. Journal of Tropical Forest Science 11(3):519-527.

Phillips, L.E. 1993. Urban Trees: A Guide for Selection, Maintenance and Master Planning. McGraw-Hill, Inc. 273 pp.

Richards, N.A. 1983. Diversity and stability in a street tree population. Urban Ecology 7:159-171.

Salleh, M.N., Y.K. Wong, and F.S.P. Ng. 1990. The Tropical Garden City - Its Creation and Maintenance. Malayan Forest Record, No.33, Forest Research Institute Malaysia, Kuala Lumpur. 19 pp.

Sanders, R.A. 1981. Diversity in the street trees of Syracuse, New York. Urban Ecology 5:33-43.

Sanderson, F.R., Y.K. Fong, and A. Saiful. 1997. A Fusarium wilt (Fusarium oxysporum) of angsana (Pterocarpus indicus) in Singapore. Journal of Arboriculture 21(3):205-214.

Schroeder, H.W., and S.R. Ruffolo. 1996. Householder evaluations of street trees in a Chicago suburb. Journal of Arboriculture 22:237-243.

Siti Rubiah, Z. 2008. Diversity of urban trees at protocol and residential roads in Kuching City North, Sarawak and their Management Issues. pp. 71-80. In: E. Philip, M. Sreetheran, and M.N. Ahmad Azarudin (Eds.). Proceeding of the Urban Forestry Conference: Managing Urban Green for Sustainable Cities, Gemilang Press Sdn. Bhd, Sungai Buloh, Malaysia.

Smith, W.H. 1990. Air pollution and forests. Springer-Verlag, New York.

Sullivan, W.C., and F.E. Kuo. 1996. Do Trees Strengthen Urban Communities, Reduce Domestic Violence? Technical Bulletin R8-FR56. USDA Forest Service, South Region, Atlanta.

Sun, W.Q. 1992. Quantifying species diversity of streeside trees in our cities. Journal of Arboriculture 18:91-93.

Thaiutsa, B., L. Puangchit, R. Kjelgren, and W. Arunpraparut. 2008. Urban green space, street tree and heritage large tree assessment in Bangkok, Thailand. Urban Forestry and Urban Greening 7:219-229.

Tho, Y.P, K.M. Wong, S.K. Yap, and K.M. Kochummen. 1983. Towards a uniquely Malaysian urban landscapes through an emphasis on the planting of indigenous trees. pp. 281-289. In: W.M. Wan Sabri, M. Rusli, A. Kamis, H. Mohd. Basri, and J. Mohd Zin. (Eds.). Outdoor Recreation in Malaysia, Universiti Pertanian Malaysia, Selangor Darul Ehsan, Malaysia.

Trowbridge, P.J., and N.L. Bassuk. 2004. Trees in the Urban Landscape: Site Assessment, Design and Installation. John Wiley \& Sons, New Jersey. 207 pp.

Tyrväinen, L. 2001. Economic valuation of urban forest benefits in Finland. Journal of Environmental Management 62:75-92.

Ulrich, R.S. 1984. View through a window may influence recovery from surgery. Science 224:42-421.

Valentine, F.A., R.D. Westfall, and P.D. Manion. 1978. Street tree assessment by a survey sampling procedure. Journal of Arboriculture.4:49-57.

VanDruff, L.W., D.L. Leedy, and F.W. Stearns. 1995. Urban wildlife and human being. pp. 203-211. In: H. Sukopp, M. Numata, and A. Huber (Eds.). Urban Ecology as the Basis of Urban Planning. SPB Academic Publishing, Amsterdam.
Wee, Y.C. 2003. Tropical Trees and Shrubs: A Selection for Urban Plantings. Sun Tree Publishing Limited, Singapore. 392 pp.

Wee, Y.C., and R. Corlett. 1986. The City and the Forest: Plant Life in Urban Singapore. Singapore University Press, Singapore.

Wolf, K.L. 2004. Trees and business district preferences: A case study of Athens, Georgia. Journal of Arboriculture 30:336-321.

Wolowicz, R.S., and M. Gera. 2000. Tree inventory and systematic management. pp. 95-106. In: J.E. Kuser (Ed.). Handbook of Urban and Community Forestry in the Northeast. Kluwer Academic/Plenum Publishers, New York

Sreetheran Maruthaveeran (corresponding author)

Research Officer

Forest Research Institute Malaysia

Kepong, 52109

Selangor, Malaysia

sreetheran@frim.gov.my

Adnan Mohammad

Research Officer

Forest Research Institute Malaysia

Kepong, 52109

Selangor, Malaysia

Khairil Azuar Abdul Khalit

Research Assistant

Forest Research Institute Malaysia

Kepong, 52109

Selangor, Malaysia

Résumé. Les programmes de plantation en Malaisie ont progressé tel que planifié. Néanmoins, la gestion subséquente des arbres de rues, particulièrement à l'hôtel de ville de Kuala Lumpur, n'est pas bien prise en main en raison d'une information inadéquate à propos des objectifs de gestion et d'entretien. Il n'y a jamais eu d'inventaire systématique des arbres de rues mené à Kula Lumpur. Face à cela, un inventaire a été fait pour recueillir des informations détaillées sur la structure des arbres, la composition en espèces, ainsi que les défauts et les désordres chez les arbres. Un total de 2191 arbres de rues ont été inventoriés.

Zusammenfassung. Die Baumpflanzprogramme in Malaysia sind wie geplant vorangeschritten. Dennoch sind die subsequenten Verwaltungsarbeiten der Strassenbäume, besonders bei der Stadthalle in Kuala Lumpur wegen der inadäquaten Information über Management und Erhaltungsmassnahmen nicht so gut vorbereitet. Es hat in Kuala Lumpur noch nie ein systematisches Baumkataster der Strassenbäume gegeben. Mit diesem wurde eine Bauminventur durchgeführt, um umfassende Daten zur Baumstruktur, Artenzusammensetzung, Artenvielfalt, Baumschäden und Defekte zu sammeln. Insgesamt wurden 2.191 Bäume untersucht.

Resumen. Los programas de plantaciòn en Malasya han progresado en la planeaciòn. Sin embargo, el manejo subsecuente de àrboles urbanos, particularmente en Kuala Lumpur City Hall, no es bien entendido debido a la informaciòn inadecuada para propòsitos de manejo y mantenimiento. No ha habido una medición sistemática de los árboles en Kuala Lumpur. Con esto, se llevò a cabo una encuesta para colectar informaciòn de la estructura del àrbol, composiciòn de especies, diversidad, defectos y desòrdenes de los àrboles. Se evaluaron un total de 2,191 àrboles. 
APPENDIX. SURVEY FORMAT USED FOR EXISTING STREET TREES IN KUALA LUMPUR, MALAYSIA.

Name:

Street:

Date:

\section{Tree Characteristics}

Tree ID:

Species:

Local Name:

DBH:

Height:

Spread:

Form:

$\square$ generally symmetric

$\square$ minor asymmetry

major asymmetry

\section{Site Condition}

Site topography:

$\square$ flat

$\square$ slope

$\square$ others:

Root surface cover:

$\square$ paved ...........\%

$\square \quad$ turf .............\%

$\square \quad$ bare soil ..........\%

$\square$ others:

\section{Tree Health}

Foliage color:

$\square$ normal

$\square$ chlorotic

$\square$ necrotic

Foliage density:

$\square$ dense

$\square$ sparse

Vigor class:

$\square \operatorname{good}$

$\square$ average

$\square$ poor

\section{Hazard Status}

Trees defect:

$\square$ poor taper

$\square$ co-dominants

$\square$ multiple attachments

$\square$ included bark

$\square$ excessive end weight

$\square$ cracks

$\square$ hangers

$\square$ girdling

$\square$ wounds

$\square$ decay

$\square$ cavity

$\square$ conks/mushroom

$\begin{array}{ll}\square & \text { sap flow } \\ \square & \text { loose/cracked bark } \\ \square & \text { deadwood/stub } \\ \square \quad \text { termites/ants } \\ \square \quad \text { cankers } \\ \square \quad \text { galls } \\ \square \quad \text { lean } \\ \square \text { exposed root }\end{array}$

Tree part most likely to fail:

Target under the tree:

$\begin{array}{ll}\square & \text { building } \\ \square & \text { parking } \\ \square & \text { traffic } \\ \square & \text { pedestrian } \\ \square & \text { landscape } \\ \square & \text { hardscape } \\ \square \quad \text { utility lines }\end{array}$

Can target be moved?

$\square$ yes

Occupancy:

$\square \quad$ occasional use

$\square$ frequent use

constant use

Hazard ratings:

$\square \quad$ low

$\square \quad$ medium

$\square$ high

severe

Hazard abatement:

$\square \quad$ remove defective part

$\square$ reduce end weight

$\square$ crown clean

$\square$ crown thin

raise canopy

\section{Comment}

